\title{
A WILLING EXISTENCE: THE CARE OF THE MOTHER TO THE CHILD/ADOLESCENT WITH CEREBRAL PALSY
}

\author{
UMA EXISTÊNCIA SOLÍCITA: O CUIDADO DA MÃE À CRIANÇA/ADOLESCENTE \\ COM PARALISIA CEREBRAL
}

\begin{abstract}
Vera Lucia FREITAG ${ }^{1}$; Viviane Marten MILBRATH²; Danieli Samara FEDERIZZI; Indiara Sartori DALMOLIN ${ }^{4}$; Zaira Letícia TISOTT ${ }^{5}$

1. Teacher of Nursing at the University of Cruz Alta (UNICRUZ). Doctoral Student in Nursing, Graduate Program in Nursing. (PPGEnf), Federal University of Rio Grande do Sul (UFRGS). Master in Health Sciences. Nurse. Rio Grande do Sul (RS), Brazil. Email: verafreitag@hotmail.com. 2. Teacher Nursing Course and PPGEnf at the Federal University of Pelotas (UFPel). PhD in Nursing from UFRGS. Nurse. RS, Brazil. 3. Specialist in Pediatrics and Obstetrics. Nurse. Paraná, Brazil. 4. Doctoral Student in Nursing at PPGEnf, Federal University of Santa Catarina (UFSC). Master in Nursing at UFSC. Paraná, Brazil. Doctoral Student in Nursing at PPGEnf / UFRGS. Master in Nursing. RS, Brazil.
\end{abstract}

\begin{abstract}
To understand the care of the mother to the child/adolescent with cerebral palsy. A qualitative study with a hermeneutical phenomenological approach based on Heidegger and Ricoeur. It was developed with ten mothers of child/adolescent with cerebral palsy who attend an Association of Parents and Friends of Special of a city located in the north of the State of Rio Grande do Sul/Brazil. The information was collected through the phenomenological interview, from April to June 2015 and was interpreted with the hermeneutics of Ricoeur. The results showed that the mother of the child/adolescent with cerebral palsy reorganized her life in order to dedicate herself exclusively to the care of the child, offering her the maximum of existential possibilities. The being-in-the-world of these mothers is to be-with the child in a bond so intense that the mother in many moments is understood as part of the corporality of the son. Due to the range of complex care that the mother dedicates to the child/adolescent with cerebral palsy, it is necessary that the health professionals, especially the nurse, put themselves in the presence of the mother, and taking care of it as a way of being in care.
\end{abstract}

KEYWORDS: Cerebral Palsy. Child Care. Adolescent Health. Mothers. Hermeneutics.

\section{INTRODUCTION}

The family, especially the mother of the child/adolescent with cerebral palsy, is exposed there are various manifestations in the day-to-day, which cause anguish, as the eyes of the people on the street and the questions related to the child who lives under this condition. There is a rupture of the social contacts, since the majority of mothers is no longer working, studying and even perform leisure activities, depending on the care of the child, fact that significantly changes the dynamics of the lives of these women. With the abandonment of these activities, they forget their desires and dreams, channeling their energies and efforts toward the provision of care to the child (ALMEIDA; RABINOVICH, 2014).

The being-in-the-world of these mothers is permeated by the childcare. However, simple daily care to the child/adolescent can generate difficulties and ambiguous feelings, both by the limitations of the child, and the emotional confusion experienced by the mother, who assumes full responsibility for such care, because they consider their essential advocate (PEREIRA et al., 2014).

The care offered to children is a complex act, which result from factors such as culture, beliefs and experiences of the mother (AHMADIZADEH et al., 2015). The presence is a loved that, being, is already at stake his own being, in this case the child with cerebral palsy. In the ontological constitution of understanding, it is evident the area in the game, as the being who is projected for the able-to-bemore-oneself, i.e., the mother caregiver must make adjustments in her daily care to be able to be with the being cared of (HEIDEGGER, 2013).

The implications of the demands of the mothers caregivers of children/adolescents with special needs, as well as the way in which women face the situation is directly related to their social and cultural context. These pass through various approaches, such as the escape, of active, confrontation, anxiety and seek different ways of dealing with the situation, trying to make it less stressful and less harmful to their well-being.

In this sense, the mothers are daily challenged to balance various demands as frequent 
medical visits, hospitalizations, surgeries, therapy sessions and intensive domiciliary rehabilitation schemes, with the demands of care of their other children, marriage and professional life. These demands often generate a workload in the lives of these women; however, are seeking to meet all these demands, especially those who believe that will benefit the child with special needs (BURKHARD, 2013).

Cultural expectations as to gender, family relationships, domestic work and child rearing that permeate the society make that mothers give themselves to the care of children, even though this denial materializes in the form of voluntary sacrifice. The mother, many times, transcends the limits, in favor of the welfare of the child/adolescent, as well as the whole family. However, when workloaded, stressed or worn out, can present health problems, such as tiredness, irritability and impotence (DEHGHAN et al., 2016) that leads to social isolation, in the development of deep stress, depression and a reduction in quality of life (AHMADIZADEH, MOKHLESIN, 2014; AHMADIZADEH et al., 2015).

The psychological and physical health of the caregivers can be strongly influenced by the severity of impairment of cerebral palsy and the demand for care. Thus, the process of taking care of the child together with the growth of the responsibilities that this function promotes, you can reduce your free time, change your professional situation and raise the financial load, as well as lead to tiredness, isolation, frustration, workload and stress of caregivers. In this way, the mother of the child/adolescent with cerebral palsy alters her life according to the comfort of the child, starting not to develop her social roles (CZUPRYNA, NOWOTNY-CZUPRYNA, 2014).

Another important factor is the dialog between health professionals and mothers. This care is so fragile, with the use of technical terms that make it impossible in many moments an understanding. In addition, mothers face difficulties on a day to day basis, how to feed the child/adolescent, helping to move, care with hygiene, follow the treatments, among other activities (MILBRATH, 2013; PEREIRA et al., 2014). The mother of the child/adolescent with special needs live a daily workload, with the responsibility of taking care of other children and also take account of domestic demands.

Now, it emphasizes the importance of the nursing staff to understand the complexity that concerns the be-mother and caregiver of a child/teenager with cerebral palsy, so that you can think of care strategies able to assist this woman both in care for the child as in her self-care. It is to look for that child/adolescent and his mother as human beings entered into the world, that experience in a unique way the vulnerability to exist as a human being.

In this context, we elaborated the following guiding question: How does the mother take care of children/adolescents with cerebral palsy? The objective of this study was to understand the care of mother to child/teenager with cerebral palsy.

\section{MATERIAL AND METHODS}

This is a qualitative research in the light of a phenomenological-hermeneutic approach, based on Heidegger and Ricouer (RICOEUR, 1978; HEIDEGGER, 2013). It was developed in the Association of Parents and Friends of Exceptional Children (APAE) of a municipality located in the northern region of the State of Rio Grande do Sul, with the participation of ten mothers and caregivers of children in pre-school age last year, children from 5-12 years old and adolescents aged 13-18 years old according to the Statute of the Child and Adolescent (ECA) with special needs resulting from cerebral palsy.

The collection of information was carried out by the main researcher, in the period from April to June 2015, using the phenomenological interview guided by the question: You can tell me how to care for a child (child/adolescent) with cerebral palsy, being at six in the domicile of participants and four in the APAE, with an average duration of 50 minutes. For the interpretation of the information used to Paul Ricoeur's hermeneutic (RICOUER, 1978).

The inclusion criteria were: to be the mother and caregiver of the child/adolescent with special needs resulting from cerebral palsy; the child/adolescent age between 5 and 19 years old; attend the study site; not be traveling or away from the institution during the period of collection of information; and the mother have age greater than or equal to 18 years old. Moreover, as exclusion criteria: present difficulty in verbal communication.

There were respected the ethical precepts established by Resolution N 466/12 of the National Health Council of the Ministry of Health (BRASIL, 2012) The project was approved by the Medical School of the Federal University of Pelotas/RS Brazil, by detailed opinion $N 1,001.573$ on $26^{\text {th }}$ March 2015. In order to keep the anonymity of the participants were represented by the letter " $M$ " is 
the "Mother" and the numbers were consecutively according to the order of the interviews.

\section{RESULTS AND DISCUSSION}

\section{Revealing meanings "he is my life, i live for him"}

The phenomenon that is revealed with the mothers of children/adolescents with cerebral palsy, by means of the phenomenological interview, there was permeated by their concerns in relation to the care of the child. It manifests itself through the space where the mother passes especially the care in the family core and therapeutic environment. They are existential manifestations of presence as being in the world and being-in-the-world-with-the-other, in this case being-in-the-world-with-the-son.

In this scenario, the care is understood as the soil in which moves the completely human interpretation. Only from the dimensions of care is that the desire and the wish to emerge as the presence of humans. Care then means devotion, care, diligence, zeal, attention, good treatment. It is a fundamental attitude of a mode of being, in which the person goes out of itself and focuses on the other with devotion and concern (BOFF, 2014).

These mothers, to adopt an authentic way of caring, makes the child with special needs the center of action in their lives. In this sense, caring for someone, it is be-with-he is living-with-someone, caring for someone, it is helping to ensure that the other is, is to promote, protect its integrity and unity of their being (ROSSELÒ, 2009).

The care is only possible as presence. To be with the other is that it makes it possible to take care of the other (HEIDEGGER, 2013). The son is a constant presence in the world of these mothers. The statements show this relationship of care, as the mothers put together/beside her son, exempting a solicitous care:

Since the time that I raise he is, my day is the day of him, because we live in his function, then rise with him in her lap. I must banish the foot, even if I am in front of home do I have to leave him somewhere that he can see me, I cannot lose sight of (M4).

Alone I do nothing, always with him together, [...] where I am going, since market, pharmacy, has to take him along, he is not even in the time of the bathroom I have to put it inside the bathroom along with me for him to see that I am there, hence I take bathroom and he is there in the bathroom (M9).

The testimonies allow a reflection about the relationship between mother/child, prompting the question: "Who cannot lose sight of who?" The need to keep a visual contact between the dyad mother/child often occurs by a maternal insecurity that with the passing of time ends up generating insecurity in their own child/adolescent. Experience the detachment of the figure of affection, in the case of the mother, it is important for the child's emotional development, so that he can learn that even the mother out of his field of vision it back, this allows for the creation of courage to explore safely the world.

The children/adolescents distress themselves when the mother disappears from their visual field, because at that moment imagine that the mother has ceased to exist and that she is helpless. This experience is necessary and virtually inevitable for the child/adolescent matures and discovers, gradually, that the mother is still alive, that she may go, but will return. To the extent that make these discoveries, learn to wait and to tolerate the limits, developing a positive attitude toward life and people (DIAS, CASTRO, ROCHA, 2010).

It is perceived that a large part of the mothers have, at some time in their lives, and difficulty to move away from their child, for various issues, such as perceiving it fragile, vulnerable, or even for fear that he forget her. This situation is of nuances of larger proportions when the child/adolescent has special needs, because the mother beyond these fears, also experiences the fear that the child has a convulsion, choke or has a fall, especially when it is unable to speak and, thus, cannot ask for help.

Because of the demands of care that a child/teenager with cerebral palsy needs from day to day, their mothers dedicate their lives to caring for them, leaving to the background, many times, the care for herself, making themselves co-responsible by existential itinerary be careful, exerting all its potential for thinking that the child care only belongs to her, and that it is not its job to transfer this responsibility to another. In this sense, in the very moment, the mother imagines the possibility of the child not being, in the sense that something bad can happen to it and get out all the possibilities to exist.

As a being-in-the-world, these mothers experience in their daily occupation and choose to occupy their time with the care to the child. The time that has or has not is always time. ${ }^{4}$ Therefore, the mothers donate their time to be with the son and be with him, in a relationship of care. As you can see in the following statement:

Thus, during the day, since the time that I agree with him, our routine is the same. Changing a diaper, get out of bed, give the medicine, give the 
maker, take it to sunbathe, and around him always, achieving something, another, trying to teach him catch another, and is thus, do lunch, change diaper again, hence bathroom in the afternoon, we are going (M2).

The time is for it, then I am well (M10).

The mothers' statements reflect the perspective of care in which, caring for someone briefly, is not to care for it, because the solicitous care demands time and fidelity in time. Anchored in this statement, we can say that it is in this sense that the mothers care for children, a care that demands time, fidelity in time and persistence (ROSSELÒ, 2009).

This donation is intense, to the point that, often, the mother is part of the life of children/adolescents in a way so rooted that comes to be perceived by her as part of its corporeity (MILBRATH et al., 2016). By testimonials we can observe that the mothers live for their children and children with special needs, a fact which was also found in other studies (SILVA, RAMO, 2014).

It should be emphasized that this is an existential mode of being in accordance with the mode-of-being one who is near us, the being-in-theworld-with-the-other is experiencing a way-of-being of care (HEIDEGGER, 2013).

In the perspective of these mothers are being-in-the-world with and by the child, can be seen in the following speeches that the interaction between the dyad mother/son can determine the feeling of these women in relation to their day-today basis:

He is my life, the only son who had [...] when he's well everything well, when he is not well nor I am well (M2).

I deny myself. He is well, I am well (M4).

It is essential to reflect on how the mother feels in relation to her day, because it is attached to another being, in this case, the child with special needs; the mother acquires an authentic way of being a caregiver of a child/teenager with cerebral palsy.

A study that sought to identify the personal experiences of mothers in care of children with cerebral palsy related to personality characteristics of this, as the mood and beliefs, concluded that these resources are used to coping with the overhead associated with the care of the child (ROPER et al., 2014). Thus, it can be said that the mood state of the mother is linked to the health condition of the child.

The mothers, to experience the existential reality of having a child with cerebral palsy and to adopt a genuine attitude of care, end up abdicating from other roles they played to take care of the child, leaving to work, study, to be only mothers, in which the care if mixing between the concern, resignation, but, above all, devotion compensated by neurological gains arising from the development of the child. The same author says that mothers take care for the child/adolescent adopting a critical vision that they are taking care of themselves, so take care of her son in a meaningful way (BURKHARD, 2013).

In this perspective, the mothers experience at many moments in a process of annulment of his own identity and dedication in relation to the son is so intense that the mother puts her own existence in background, nullifying herself as being-in-the-world at the expense of caring for the child.

The caring mother lived this existential reality of having a child with cerebral palsy and has decided to adopt an attitude of authentic and caring for the child, but each one in his singularity, decided how would take care, placing themselves in the background while being in the world, to live with her son, walking beside him. As you can see in the statements that follow:

I am concerned only with him [...] first he (M2).

I deny, you know, my life is to him [...]. If I'm in a child, that are very close (referring to other children), he goes along, if he goes in college, I go along. Then, I live his life (M4).

When you have a special child, you think him, and no longer think in it, I forget that I also need to take care of (M9).

The mother of a child/teenager with cerebral palsy, often cancels while person/woman and expresses exclusively in their personality characteristics of this new and inflexible function being a mother, restricting themselves to the care process, passing between the family and the therapeutic environment. Soon, this scenario reduced interpersonal interactions is configured as a limiting factor for the development of these mothers, which, subsequently, may be set up in a deep sense of frustration (WHITING, 2014).

In this way, it is observed that the woman, when becoming mother to a child/teenager with special needs, (re) organizes their way of being-inthe-world, reestablishing their priorities, puts in the background all roles that it plays, including the right to be women, to assume, almost exclusively, the role of being a mother of a child with special needs resulting from cerebral palsy.

The prioritization of the role of being a mother in favor of abdication of her other roles, as a worker, a woman, wife, friend, was also found in another study (COSTA et al.; 2013; SANTOS, 
A willing existence...

MARQUE, SOUZA, 2017). When choosing the role of being a mother, these women prioritize the needs of the child/adolescent, as seen in the following:

There are people, nor that lack the things for tomorrow, go get your hair, these things. I don't, $I$, is left. The first is my daughter, I'm going there, fill of medicine (M7).

The previous statement describes that, firstly, this mother puts the care with the daughter, mainly related to the use of medications, which usually children/adolescents make use the end of a better quality of life.

The study concluded that the majority of caregiver mothers face financial difficulties, and that in many times, is a factor of interference in the care with the children/adolescents, because need medicines, transportation, diapers, adequate food and not always the monthly income meets these demands. Mothers usually cannot work outside the home, because the routine care with the special child demand full time making this conciliation (PEREIRA et al., 2014).

Some of the participants take care of children with special needs to the point of they realize as an extension of its corporeity:

I agree and I will deal, take milk, do the service, first he (referring to the child with special needs), give food to him, first of all, washing machine, then I'll make lunch [...] when I take milk also I have to take it, make the likes him (M3).

I take coffee with my friends, who are all nearby, then go back to home, lunch in the mother, sometimes at home, sometimes step the whole day strolling [...], wash clothes, these things (M5).

As can be observed in the statements, when the mother says: "I agree and I will deal, take milk", is talking that she will take milk, perceiving them if only one person, uses the "I", although please say "we" (mother/child). In the same way, when the M5 puts it: "I'm going to take coffee with my friends, who are all nearby, then go back to home, lunch in the mother, sometimes at home" also uses the "I" wanting to refer to "we". It is as if it was necessary to say that perform these activities with your children, because it is natural for them, is part of everyday life. In this way, the child/adolescent is to be perceived by the mother as an extension of its corporeity.

A similar situation was found in relation to children/adolescents with cerebral palsy in relation to their mothers, because in many moments are not aware of the presence of the mother, because there is an interaction that makes the child realizes the mother as part of his being and, in this way, do not see the need to express that the mother is beside her,
FREITAG, V. L. et al.

because that is part of her day to day. It is as if the mother was part of their existence (MILBRATH, 2013).

In the Heideggerian perspective, "the beingwith determines existentially the presence, even when the other is not, in fact, given or perceived. Even the area only the presence, is being-with the world. Only in a being-with and for a being-with, is that another may miss" (HEIDEGGER, 2005).

The perception of the mother as part of the embodiment of the child is a common fact in studies. It can be observed that for the mother, the "I" and the "other" are the constituent parts of the same corporeity. Thus, the corporeality is relational aspects, social, cultural and historical heritage, representing a complex of experiences and interactions (MILBRATH et al., 2016).

At this level, the interaction between mother and son, allows the mother, in many moments, is not because of the presence of the Son, perceiving them as a single person, i.e., seeing the son as part of its corporeity.

Based on Heideggerian thought, the mother was launched in a world that was not chosen before many conditions, among them, live next to the child with cerebral palsy, in a world that is not formed of topographical areas delimited, but many unexpected situations that constitute a life, in which the presence existentially is characterized by the ableto-be. The being-in-the-world is enveloped by circumstances shared with the Son on a day-to-day basis. The maternal presence goes back to the Son by means of care. This care is carried out by the mother and comes to the fore by switching between the modes of pre-occupation and occupation, in spite of the presence itself lead him as a unique way of caring.

The concern regarding the future of the child/adolescent causes the mother to devote themselves fully to the children in an attempt to provide him the maximum of existential possibilities for the development of your entire being-able-to-do, since they fear the own finiteness:

I'm more at home to protect him, even when the physiotherapist does not meet, I do physical therapy at home, because she has taught me, is that good care, protect him, because life is a boat and have health problems, then, who will take care of him? (M2).

I think well of him, I despair, that the life of the people is borrowed, we don't know until when, but then you ever thought if we miss, what is going to be a child of that? (M4).

My daughter I think very well [...] I had a nodule within [...] Hence one day my sister came 
here (home) and I told her that I was giving my girl for her. I thought I will give to my sister, because her father will not give, never cared, I thought you know because my mother died of cancer, so I thought if I'm going to die I will give the girl of paper passed to it before dying [...] many call me crazy but this is not going to do that, I always think (M7).

The mothers fear death itself because they fear the future of their children. The participants expressed concern with the lives of their children after cease to exist. In other research, researcher found that mothers of children/adolescents with cerebral palsy to perceive themselves as a finite being intimidating and concern themselves not with their finitude in itself, but about the future of their children if the physical absence of the mother happen (MILBRATH, 2013).

In the Heideggerian perspective, what is fear, the fear and the fear, the fear it configures itself as a threat, something that can cause damage (HEIDEGGER, 2013) i.e. the mother sees fearful in the face of the impossibility of the Son and his finitude. The mother fears its finiteness as being-inthe-world in their daily life. This possibility of finitude that can reach or not, does not diminish neither solves the fear of the mother.

The concern with the future appears reflected in doubt concerning what will happen to the child after the finiteness of their parents and the need reported by mothers in ensuring the future of their child with cerebral palsy (CUNHA, PONTES, SILVA, 2017). Parents need to transfer responsibility of care for the child/adolescent with cerebral palsy to other subsystems of the family, usually the brotherly subsystem, for which the child receives the attention it needs after his death.

This fear of the future is related to care. The mothers are concerned with who can take care of the child in their finitude, fear that the children might pass through prejudice in their day-to-day, without the presence of mother, are afraid of not being able to take care of their children forever, and that they can pass through discrimination and mistreatment.

The mothers care for children in a mode of interaction so intense that many times are not aware of the presence of the child, perceiving them as a single person. The caring for a child with special needs involves many peculiarities, can in some situations cause insecurity for the mothers, which can be minimized with an adequate approach of health staff, especially nursing that can serve as a support network for these mothers, helping them to take care of themselves, taking care of their child, perceiving it as a being in the world, which also need to be careful.

When seeking to understand the care of mother to child/teenager with cerebral palsy, it was possible to achieve a rapprochement with the daily reality of these mothers, emerging from the reflection on the exist as a human being exposed to various existential facticities and the ability to overcome by adopting an attitude of authentic and dedication to the other, in this case, the child with special needs.

After the process of upgrading/reorganization mothers devote themselves fully to the care of the son, making the child/adolescent the center of attention of their lives, to the point to understand yourself as a single person in many moments. This fact leads mothers to abdicate their lives at the expense of care to the child. To perceive themselves as a finite being seeks to offer the maximum of care that can foster the independence of the son.

The survey was limited by the lack of scientific productions that address the complex process of caring for a child/teenager with cerebral palsy, as well as the use of hermeneutic phenomenology as a methodology. Instigates that further investigations are undertaken in other contexts and institutions.

We believe that studies such as this one might raise awareness among health professionals, especially nurses, as well as the managers of health care to the family, primarily to the mother of the child/adolescent with cerebral palsy, in the enforcement of public policies and rights neglected, taking into account their special features, its history, its culture, centered on the otherness of the being.

RESUMO: Compreender o cuidado da mãe à criança/adolescente com paralisia cerebral. Estudo qualitativo com abordagem fenomenológica hermenêutica baseada em Heidegger e Ricoeur. Foi desenvolvido com dez mães de criança/adolescente com paralisia cerebral, que frequentam uma Associação de Pais e Amigos dos Excepcionais de uma cidade localizada ao norte do estado do Rio Grande do Sul/Brasil. A coleta das informações por meio da entrevista fenomenológica, ocorreu no período de abril a junho de 2015 e foram interpretadas com a hermenêutica de Ricoeur. Os resultados mostraram que a mãe da criança/adolescente com paralisia cerebral reorganiza sua vida a fim de dedicar-se exclusivamente ao cuidado do filho, ofertando-lhe o 
máximo de possibilidades existenciais. O ser-no-mundo destas mães é ser-com o filho em uma ligação tão intensa que a mãe em muitos momentos se compreende como parte da corporeidade do filho. Devido a gama de cuidados complexos que a mãe dedica a criança/adolescente com paralisia cerebral, faz-se necessário que os profissionais de saúde, em especial o enfermeiro, coloquem-se como presença aproximando-se da mãe, percebendo-a e cuidando-a como modo de ser na solicitude.

Hermenêutica.

PALAVRAS-CHAVE: Paralisia Cerebral. Cuidado da Criança. Saúde do Adolescente. Mães.

\section{REFERENCES}

AHMADIZADEH, Z.; MOKHLESIN, M. Factors Which Affect the Depression of Mothers with Cerebral Palsy Child. Iranian Rehabilitation Journal, USA, v. 12, n. 4, p. 43-8, dec. 2014. https://doi.org/10.1016/j.pedn.2013.01.001.

AHMADIZADEH, Z.; RASSAFIANI, M.; KHALILI, M. A.; MIRMOHAMMADKHANI, M. Factors associated with quality of life in mothers of children with cerebral palsy in Iran. Hong Kong Journal of Occupational Therapy [Internet newspaper], v. 17, n. 25, p. 15-22, june. 2015.

https://doi.org/10.1016/j.hkjot.2015.02.002.

ALMEIDA, C. F.; RABINOVICH, E. P. Redes de cuidado de crianças com paralisia cerebral. Diálogos Possíveis, v. 12, n. 2, p.170-88, 2014.

BOFF, L. Saber Cuidar: Ética do humano - compaixão pela terra. 20ª ed. Vozes Ltda, São Paulo, 2014.

BRASIL. Resolução 466, de 12 de dezembro de 2012. Dispõe sobre diretrizes e normas regulamentadoras de pesquisas envolvendo seres humanos, 2012. Disponível em:

http://bvsms.saude.gov.br/bvs/saudelegis/cns/2013/res0466_12_12_2012.html.

BURKHARD, A. A different life: caring for an adolescent or young adult with severe cerebral palsy.

Journal of Pediatric Nursing, USA, v. 28, n. 4, p. 357-63, 2013 jul/aug. 2013.

https://doi.org/10.1016/j.pedn.2013.01.001.

COSTA, E. A.; PINTO, N. M. A.; FIÚZA, A. L. C.; PEREIRA, E. T. Paralisia cerebral e cuidado: o que muda na vida de quem cuida? Oikos: Revista Brasileira de Economia Doméstica, Viçosa, n. 24, v. 1, p. 236-64, 2013. http://www.locus.ufv.br/handle/123456789/13888.

CUNHA, K. D. C.; PONTES, F. A. R.; SILVA, S. S. D. C. Pais de crianças com paralisia cerebral pouco estressados. Revista Brasileira de Educação especial, n. 23, v. 1, p. 111-26, 2017.

http://dx.doi.org/10.1590/s1413-65382317000100009.

CZUPRYNA, K.; NOWOTNY-CZUPRYNA, O.; NOWOTNY, J. Back pain in mothers of cerebral palsied children. Ortopedia Traumatologia Rehabilitacja, v. 16, n. 5, p. 497-505, set-out. 2014. DOI: 10.5604 / 15093492.1021812 .

DEHGHAN, L.; DALVAND, H.; FEIZI, A; SAMADI, S. A.; HOSSEINI, S. A. Quality of life in mothers of children with cerebral palsy: The role of children's gross motor function. Journal of Child Health Care, USA, v. 20, n. 1, p. 17-26, mar. 2016. https://doi.org/10.1177/1367493514540816.

DIAS, I. M. Á. V.; CASTRO, F. D. B.; ROCHA, S. M. M. Mãe e Filho: a eterna ligação. Editora UFJF, Juiz de fora, 2010. 72p.

HEIDEGGER, M. Ser e Tempo. Vozes, Petrópolis (RJ), 2005, p.172. 
HEIDEGGER, M. Ser e Tempo. Vozes, Petrópolis (RJ), 2013.

MILBRATH, V. M. Criança/adolescente com paralisia cerebral: compreensões do seu modo de ser no mundo [tese]. Porto Alegre (RS): Universidade Federal do Rio Grande do Sul, Programa de Pós-Graduação em Enfermagem; 2013.

MILBRATH, V. M.; MOTTA, M. G. C.; RESTA, D. G.; FREITAG, V. L. Reflecting about the body situation of being a child with cerebral palsy. Journal of Nursing UFPE, Pernambuco, v. 10, n. 8, p.3119-23, aug. 2016. DOI: 10.5205/reuol.9373-82134-1-RV1008201640.

PEREIRA, A. R. P. F.; MATSUE, R. Y.; VIEIRA, L. J. E. S.; PEREIRA, R. V. S. Análise do cuidado a partir das experiências das mães de crianças com paralisia cerebral. Saúde e Sociedade, São Paulo, v. 23, n. 2, p. 616-25, abr/jun. 2014. http://dx.doi.org/10.1590/S0104-12902014000200021.

RICOUER, P. O conflito das interpretações: ensaios de hermenêutica. Imago, Rio de Janeiro, 1978.

ROPER, S. O.; ALLRED, D. W.; MANDLECO, B.; FREEBORN, D.; DYCHES, T. Caregiver burden and sibling relationships in families raising children with disabilities and typically developing children. Families, Systems \& Health - Journals, USA, v. 32, n. 2, p. 241-6, jun. 2014. DOI: 10.1037/fsh0000047.

ROSELLÓ, F. T. Antropologia do cuidar. Petrópolis: Vozes, Rio de Janeiro, 2009.

SANTOS, K. H. D.; MARQUES, D.; SOUZA, Â. C. D. Children and adolescents with cerebral palsy: analysis of care longetudinality. Text \& Context Nursing, Florianópolis (SC), v. 26, n. 2, jul. 2017.

http://dx.doi.org/10.1590/0104-07072017000530016.

SILVA, C. C. B.; RAMO, L. Z. Reações dos familiares frente à descoberta da deficiência dos filhos. Cadernos Brasileiros de Teraria Ocupacional, São Paulo, v. 22, n. 1, p. 15-23, out. 2014.

http://dx.doi.org/10.4322/cto.2014.003.

WHITING, M. Children with disability and complex health needs: the impact on family life. Nursing children and young people, n. 26, v. 3, p. 26-30, 2014.

https://journals.rcni.com/doi/pdf/10.7748/ncyp2014.04.26.3.26.e388. 